\title{
PENGARUH PERSEPSI MATEMATIKA TERHADAP HASIL BELAJAR MATEMATIKA DITINJAU DARI PERSPEKTIF GENDER SISWA KELAS V SD NEGERI DI KECAMATAN PASONGSONGAN KABUPATEN SUMENEP
}

\author{
R. Firman Nurbudi P., Tita Tanjung S., dan Ratna Novita P. \\ Prodi PGSD FKIP Universitas Wiraraja
}

\begin{abstract}
ABSTRAK
Penelitian ini bertujuan untuk mengetahui perbedaan pengaruh persepsi matematika terhadap hasil belajar matematika ditinjau dari perspektif gender siswa kelas V SD Negeri di Kecamatan Pasongsongan Kabupaten Sumenep. Penelitian ini menggunakan pendekatan kuantitatif dan teknik sampling dengan purposive sampling area. Hasil analisis data menunjukkan bahwa nilai sig untuk gender adalah sebesar 0,816 >0,05, maka dapat disimpulkan bahwa tidak terdapat perbedaan nilai metematika yang dipengaruhioleh gender. Nilai sig untuk Persepsi adalah sebesar 0,924>0,05, maka dapat disimpulkan bahwa tidak terdapat perbedaan nilai metematika yang dipengaruhi oleh tinggi rendahnya persepsi. Tidak ada perbedaan hasil belajar antara siswa kelas $V$ yang memiliki persepsi matematika tinggi dengan siswa kelas $V$ yang memiliki persepsi matematika rendah di siswa kelas V SD Negeri Sekecamatan Pasongsongan. Berdasarkan hasil analisis data, dapat disimpulkan tidak terdapat perbedaan nilai metematika yang dipengaruhi oleh gender.
\end{abstract}

Kata-kata Kunci: Persepsi Matematika, Hasil Belajar Matematika, Gender

\section{PENDAHULUAN}

Masih banyak orang yang berpendapat bahwa Matematika adalah pelajaran yang sulit, untuk mempelajarinya dibutuhkan kemauan, kemampuan, dan kecerdasan tertentu. Pelajaran matematika menjadi momok dikalangansiswa, namun hal ini sebenarnya tidak terlepas dari kesiapan guru, kesiapan siswa, kurikulum, dan metode penyajiannya, sehingga tidak mengherankan bahwa penguasaan siswa terhadap matematika kurang.

Faktor yang berpengaruh pada proses belajar diantaranya adalah persepsi. (Slameto, dalam Yeni Kartika Wati, 2003:2). Persepsi merupakan tanggapan atau penerimaan terhadap kejadian atau pengalaman yang terjadi di lingkungan. Beberapa penelitian membuktikan adanya perbedaan persepsi antara laki-laki dan perempuan. Penelitian Milgram (1979: 12) tentang persepsi siswa kelas 4, 5, dan 6 tentang tingkah laku gurunya memperlihatkan adanya perbedaan persepsi antara siswa laki-laki dan perempuan.
Selain adanya temuan penelitian tentang perbedaan persepsi laki-laki dan perempuan, beberapa penelitian lain menemukan tidak adanya perbedaan persepsi antara laki-laki dan perempuan. Misalnya penelitian Brady dan Eisler (dalam Nirwana, 2003: 28) tidak menemukan perbedaan persepsi antara mahasiswa laki-laki dan perempuan tentang perilaku dosen dalam interaksi dosen-mahasiswa, dan tidak berbedanya persepsi mahasiswa laki-laki dan perempuan tentang kesulitan-kesulitan yang berkaitan dengan pendidikan mereka (Luzzo dan McWhirter, dalam Nirwana, 2003: 29).Berkenaan dengan persepsi siswa tentang matematika, temuan penelitian Fennema (dalam Nirwana, 2003: 30) tentang persepsi siswa terhadap kegunaan belajar matematika menunjukkan adanya kaitan jenis kelamin dengan persepsi mereka. Siswa laki-laki umumnya memiliki skor persepsi yang lebih tinggi daripada siswa perempuan. Berbedanya persepsi mereka berdasarkan jenis kelamin berkaitan pula dengan 
perbedaan hasil belajar mereka dalam belajar matematika.

Manusia diciptakan berbeda satu sama lainnya, terdiri dari laki-laki dan perempuan. Dalam kehidupan sehari-hari ataupun di dunia kerja, laki-laki sangat mendominasi dalam setiap peran. Menurut Kartini Kartono (dalam Yeni Kartika Wati, 2003: 24-25), betapapun baik dan cemerlangnya intelegensi perempuan, namun pada intinya perempuan hampir-hampir tidak pernah mempunyai ketertarikan yang menyeluruh pada soal-soal teoritis seperti laki-laki. Perempuan juga lebih dekat pada masalah-masalah kehidupan yang praktis konkret, sedangkan laki-laki lebih tertarik pada segi-segi yang abstrak.

Berdasarkan latar belakang masalah maka perumusan masalah dalam penelitian ini adalah: (1) Adakah perbedaan hasil belajar matematika antara siswa laki-laki dan siswa perempuan kelas V SD Negeri di Kecamatan Pasongsongan Kabupaten Sumenep? (2)Adakah perbedaan hasil belajar antara siswa kelas $\mathrm{V}$ yang memiliki persepsi matematika tinggi dengan siswa kelas $\mathrm{V}$ yang memiliki persepsi matematika rendah $\mathrm{V}$ SD Negeri di Kecamatan Pasongsongan Kabupaten Sumenep? (3)Adakah interaksi antara persepsi matematika dan gender terhadap hasil belajar matematika siswa kelas V SD Negeri di Kecamatan Pasongsongan Kabupaten Sumenep?

\section{METODE}

Penelitian ini adalah penelitian kuantitatif, populasi dalam penelitian ini adalah seluruh siswa kelas V di SD Negeri di Kecamatan Pasongsongan Kabupaten Sumenep yaitu sebanyak \pm 5 sekolah. Sampel dalam penelitian ini adalah siswa 5 (lima) sekolah Kelas V SD Negeri di Kecamatan Pasongsongan Kabupaten Sumenep, sedangkan waktu penelitian adalah semester genap tahun ajaran 2012/2013 yang ada di sekolah ketika penelitian berlangsung.Dari populasi yang ada dilakukan uji homogenitas dua varians yang dimaksudkan untuk mengetahui homogen atau tidaknya populasi tersebut. Data yang digunakan untuk uji homogenitas ini adalah nilai matematika pada raport kelas $\mathrm{V}$ semester ganjil. Untuk menguji homogenitas varians data dua kelompok digunakan uji-F atau analisis varians (ANAVA tunggal). Prosedur penelitian ini adalah sebagai berikut :

1) Menentukan populasi dalam penelitian;

2) Melakukan uji homogenitas;

3) Membuat angket persepsi matematika dan tes matematika;

4) Uji validasi dan uji reliabilitas instrumen;

5) Revisi angket dan soal tes matematika;

6) Mengumpulkan data;

7) Melakukan uji hipotesis;

8) Menarik kesimpulan

Pengumpulan data dalam penelitian ini menggunakan teknik: (a) angket angket tertutup, yaitu yang sudah disediakan jawabannya. Angket ini digunakan untuk mencari data tentang besarnya persepsi matematika siswa.Angket tertutup yang sudah disediakan jawabannya. Angket ini digunakan untuk mencari data tentang besarnya persepsi matematika siswa. (b) Tes hasil belajar. Tes hasil belajar yang digunakan dalam penelitian ini adalah tes buatan peneliti yang isinya telah dikonsultasikan dengan guru mata pelajaran matematika di Kelas V SD Negeri di Kecamatan Pasongsongan Kabupaten Sumenep. Bentuk tes yang digunakan yaitu bentuk tes obyektif (pilihan ganda) dengan jumlah soal 20. Skor total tes maksimal 100 dan skor total tes minimal 0. Sedangkan untuk uji hipotesis dalam penenelitian ini menggunakan Analisis Varians (ANAVA) Dua Jalan dengan bantuan program SPSS 19. 


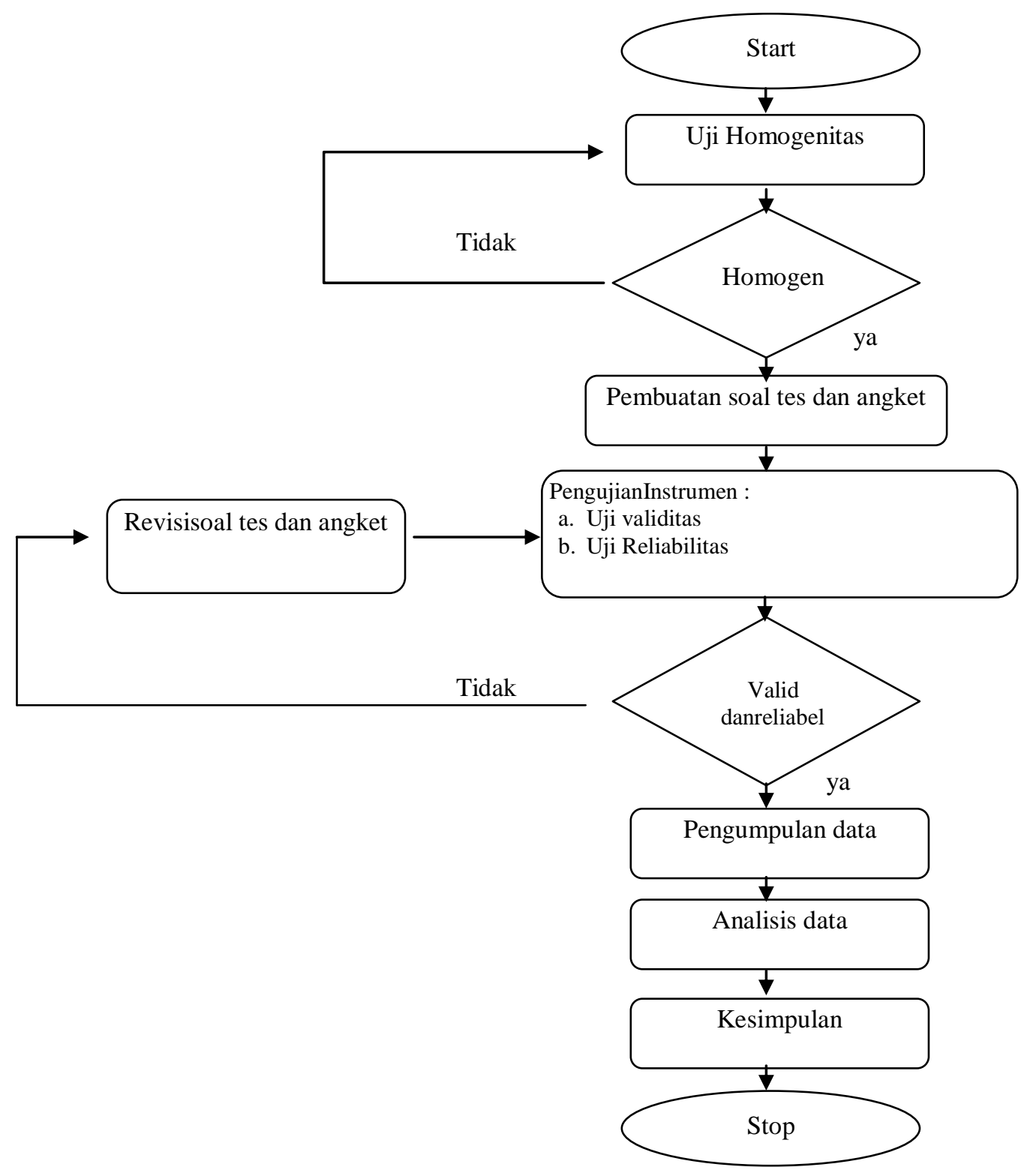

Gambar1.Rancangan Alur Penelitian

\section{HASIL DAN PEMBAHASAN}

Penelitian ini bertujuan untuk mengetahui pengaruh persepsi matematika terhadap hasil belajar matematika ditinjau dari segi gender siswa. Sehingga persepsi, gender, dan hasil belajar merupakan variabel yang diteliti. Pengambilan data persepsi siswa terhadap matematika dilakukan melalui angket dan hasil belajar melalui tes matematika siswa pada kelas $\mathrm{V}$ semester genap di kecamatan Pasongsongan. Penyebaran angket dan tes matematika dilaksanakan pada tanggal 16 sampai dengan 22 maret 2013 di 5 (lima) Sekolah Dasar pada Kecamatan Pasongsongan. Berikut jumlah responden dan waktu penelitian pada masing-masing sekolah 
Tabel 1. Komposisi Responden dan Waktu Penelitian pada Masing-Masing Sekolah di Kecamatan Pasongsongan

\begin{tabular}{|c|l|c|c|c|c|}
\hline \multirow{2}{*}{ No } & \multirow{2}{*}{ AsalSekolah } & \multirow{2}{*}{ WaktuPenelitian } & \multicolumn{3}{|c|}{ Jumlah } \\
\cline { 4 - 6 } & & & Laki-laki & Perempuan & Jumlah \\
\hline 1. & SDN Lebeng Barat & 16 maret 2013 & 5 & 7 & 12 \\
\hline 2. & SDN Sodara 1 & 19 maret 2013 & 10 & 4 & 14 \\
\hline 3. & SDN Panaongan 1 & 20 maret 2013 & 18 & 16 & 34 \\
\hline 4. & SDN Panaongan 3 & 21 maret 2013 & 9 & 8 & 17 \\
\hline 5. & SDN Pasongsongan 4 & 22 maret 2013 & 14 & 16 & 30 \\
\hline \multicolumn{7}{|l|}{ Jumlah } \\
\hline
\end{tabular}

Untuk mengetahui ada tidaknya perbedaan persepsi matematika terhadap hasil belajar matematika siswa ditinjau dari segi gender siswa digunakan analisis varians dua jalan.

Tabel 2. Jumlah Siswa Berdasarkan Nilai Tes Matematika Untuk Masing-Masing Gender

\begin{tabular}{lcc}
\hline Tingkat Persepsi & N \\
\hline Rendah & Laki-laki & 33 \\
& Perempuan & 35 \\
\multirow{2}{*}{ Sedang } & Total & 68 \\
& Laki-laki & 17 \\
& Perempuan & 10 \\
Tinggi & Total & 27 \\
& Laki-laki & 6 \\
& Perempuan & 6 \\
& Total & 12 \\
\hline
\end{tabular}

Sumberdata : data primer

Tabel di atasmenunjukkanbahwa siswa laki-laki dalam penelitian yang memiliki nilai tes Matematika rendah sebanyak 33 orang dan siswa perempuannya sebanyak 35 orang. Sedangkan siswa laki-laki yang memiliki persepsi sedang sebanyak 17 orang dan siswa perempuan sebanyak 10 orang.
Serta siswa laki-laki yang memiliki persepsi tinggi sebanyak 6 orang dan siswa perempuannya sebanyak 6 orang. Jadi berdasarkan masing-masing tingkatannya, baik siswa laki-laki dan perempuan lebih dominan pada tingakat persepsi rendah. Meskipun tidak terdapat banyak berbedaan jumlah.

Tabel 3. Hasil ANAVA Dua Jalan Tests of Between-Subjects Effects

\begin{tabular}{|c|c|c|c|c|c|}
\hline Source & Type III Sum of Squares & df & Mean Square & F & Sig. \\
\hline Corrected Model & $9561.588(\mathrm{a})$ & 44 & 217.309 & 1.015 & .472 \\
Intercept & 196658.418 & 1 & 196658.418 & 918.891 & .000 \\
G & 11.697 & 1 & 11.697 & .055 & .816 \\
$\mathrm{P}$ & 3658.798 & 28 & 130.671 & .611 & .924 \\
$\mathrm{G} * \mathrm{P}$ & 5650.739 & 15 & 376.716 & 1.760 & .062 \\
\hline
\end{tabular}




\begin{tabular}{|c|c|c|c|}
\hline $\begin{array}{c}\text { Error } \\
\text { Total } \\
\text { Corrected Total }\end{array}$ & $\begin{array}{c}13269.067 \\
313408.000 \\
22830.654\end{array}$ & $\begin{array}{c}62 \\
107 \\
106\end{array}$ & 214.017 \\
\hline
\end{tabular}

a R Squared $=.419$ (Adjusted R Squared $=.006)$

Sumberdata : data primer

Pada tabel dilihat pada Tests of Between-Subjects Effects merupakan tabel yang mempresentasikan hasil hipotesis, dengan pedoman pengambilan keputusan sebagai berikut:

a) Nilai Sig. atau signifikan atau nilai probabilitas $<\quad 0,05, \quad$ terdapat perbedaan hasil metematika antara siswa yang berpersepsi matematika rendah dengan siswa yang berpersepsi matematika tinggi ditinjau dari perspektif gender.

b) Nilai Sig. atau signifikan atau nilai probabilitas> 0,05 , tidak terdapat perbedaan hasil metematika antara siswa yang berpresepsi matematika rendah dengan siswa yang berpersepsi matematika tinggi ditinjau dari perspektif gender.

Dari output diatas terlihat bahwa sig untuk gender adalah sebesar 0,816>0,05, maka dapat disimpulkan bahwa tidak terdapat perbedaan nilai metematika yang dipengaruhioleh gender.Nilai sig untuk Persepsi adalah sebesar 0,924>0,05, maka dapat disimpulkan bahwa tidak terdapat perbedaan nilai matematika yang dipengaruhi oleh tinggi rendahnya persepsi.

Sementara untuk melihat adakah interaksi antara persepsi matematika dan gender terhadap hasil belajar matematika siswa kelas V SD Negeri di Kecamatan Pasongsongan, dapat dilihat dari $p$-value yang untuk jeniskelamin *tingkat persepsi sebesar 0,062 yang berarti dapat disimpulkan bahwa tidak terdapat perbedaan hasil metematika antara siswa yang berpresepsi matematika rendah dengan siswa yang berpersepsi matematika tinggi ditinjau dari perspektif gender. $A d j R_{\text {squared }}=0,006$ artinya nilai tes matematika dapat dijelaskan oleh 2 (dua) variabel lainnya hanya sebesar $0,6 \%$.

Tabel 4. Nilai Rata-Rata Hasil Belajar Siswa

Dependent Variable: nilai mat

\begin{tabular}{|l|r|r|r|r|}
\hline \multicolumn{1}{|c|}{ gender } & \multicolumn{1}{c|}{ Mean } & \multicolumn{1}{c|}{ Std. Error } & \multicolumn{2}{c|}{ 95\% Confidence Interval } \\
\hline & Lower Bound & Upper Bound & Lower Bound & Upper Bound \\
\hline laki-laki & $52.874(\mathrm{a})$ & 2.458 & 47.960 & 57.788 \\
\hline perempuan & $52.441(\mathrm{a})$ & 2.305 & 47.833 & 57.049 \\
\hline
\end{tabular}

a Based on modified population marginal mean.

Sumberdata : data primer

Berdasarkan hasil perhitungan statistik, diketahui bahwa nilai rata-rata hasil belajar siswa laki-laki sebesar 52,874 , nilai tersebut hanya selisih 0,433 lebih tinggi daripada nilai rata-rata hasil belajar siswa perempuan yaitu sebesar 52,441. Hal ini membuktikan bahwa nilai rata-rata hasil belajar siswa laki-laki hampir tidak ada beda dengan nilai ratarata hasil belajar siswa perempuan. Hasil perhitungan statistik ANAVA dua jalan diperoleh nilai sig $=0,816$ untuk gender terhadap hasil belajar matematika lebih kecil dari signifikansi yang ditetapkan yaitu 0,05. Dengan demikian dapat dikatakan tidak ada perbedaan hasil belajar matematika antara siswa laki-laki dan siswa perempuan di Sekolah Dasar Negeri Sekecamatan Pasongsongan, diterima dengan taraf signifikansi 5\%.

Kata gender berasal dari bahasa Inggris, berarti jenis kelamin. Dalam Webster's New World, gender diartikan sebagai perbedaan yang tampak antara 
laki-laki dan perempuan dilihat dari segi nilai dan tingkah laku (http://citraedukasi.wordpress). com/2008/01/25/penelitian-3). Belahan otak kanan laki-laki mempunyai kemampuan yang lebih kuat dibidang numerik dan logika daripada belahan otak kanan perempuan. Sedangkan belahan otak kiri anak perempuan mempunyai kelebihan dibidang estetika dan religius daripada belahan otak kiri anak laki-laki. Hal tersebut merupakan modal dasar bagi anak laki-laki untuk mengembangkan kemampuannya dalam bidang matematika.

Modal tersebut akan mempermudah seorang anak laki-laki dalam memahami materi matematika ataupun menyelesaikan permasalahan matematika yang ada. Hal ini memberi kecenderungan bahwa anak laki-laki lebih tajam daya pikirnya dalam bidang matematika daripada perempuan. Jadi, laki-laki memiliki kemampuan yang lebih daripada perempuan dalam bidang matematika.

Perbedaan gender dalam belajar matematika terus menerus menarik perhatian banyak peneliti yang dipublikasikan dalam Journal For Research in Mathematics Education. Menurut McCauley (dalam Nirwana, 2003: 34), ada perbedaan yang signifikan antara laki-laki dan perempuan dalam menguasai cara-cara memimpin suatu aktivitas. Leder (dalam Casey, dkk, 2001: 58) menyimpulkan "Learning is affected by many factor : personal, situational, and cultural". Oleh karena faktor-faktor kepribadian, situasi, dan kebudayaan mempunyai pengaruh dalam hasil belajar maka merupakan hal yang penting untuk diketahui seberapa jauh faktor-faktor itu berpengaruh terhadap hasil belajar.Salah satunya yang berkaitan dengan kepribadian adalah gender. Hingga kini telah diketahui bahwa belahan otak kanan laki-laki mempunyai kemampuan yang lebih kuat dibidang numeric dan logika dari pada belahan otak kanan perempuan. Sedangkan belahan otak kiri anak perempuan mempunyai kelebihan dibidang estetika dan religious daripada belahan otak kiri anak laki-laki. Hal ini member kecenderungan bahwa anak lakilaki lebih tajam dan lebih meminati matematika dari pada perempuan.

Namun Macoby dan Jacklyn (dalam Casey, 2001: 59) dalam bukunya mengatakan bahwa : (a) selama periode awal sekolah sampai dengan remaja kemampuan verbal anak perempuan dan laki-laki adalah sama, tetapi setelah 11 tahun kemampuan verbal anak perempuan lebih baik dari kemampuan verbal anak laki-laki, (b) laki-laki lebih baik dalam daya tilik ruang dari perempuan secara konsisten pada masa remaja dan dewasa, tetapi tidak pada masa kanak-kanak, (c) laki-laki lebih baik dalam kemampuan matematika dari perempuan, dan kira-kira mulai umur 12 tahun kemampuan lakilaki dalam matematika meningkat lebih cepat dari perempuan.

Senada dengan penelitian yang telah dilakukan. Bahwa dalam usia anak-anak (0 hingga 12 tahun) perbedaan gender itu masih belum tampak jelas. Usia sekolah dasar diasumsikan sebagai usia anak-anak yang secara kognitif masih dalam usia yang operasional kongkrit. Piaget berpendapat bahwa proses berfikir manusia merupakan suatu perkembangan yang bertahap dari berfikir intelektual konkret keabstrak melalui empat tahap perkembangan yaitu sensori motor (usia 0-2 tahun), praoperasional (usia 2-7 tahun), operasionalkonkret (usia 7-12 tahun), dan operasional formal (usia 12 tahun keatas). Dilihat dari tahap-tahap perkembangan intelektual anak, siswa kelasV SD berada pada tahap operasional konkret (usia 7-12 tahun). Sehingga dalam rentang usia ini perbedaan gender masih belum tampak secara jelas.

\section{KESIMPULAN DAN SARAN KESIMPULAN.}

Berdasarkan hasil analisa pengaruh persepsi matematika terhadap hasil belajar matematika ditinjau dari segi gender 
siswa kelas V SD Negeri di kecamatan Pasongsongan dapat disimpulkan bahwa:

1. Siswa yang memiliki nilai tes Matematika rendah sebanyak 68 orang, dan sedang 27 siswa serta yang memiliki nilai tes Matematika tinggi sebanyak 12 siswa. Hal ini menunjukkan bahwa sebagian besar $(63,55 \%)$ dari 107 siswa memiliki nilai tes Matematika rendah. 25,23\% siswa dengan nilai tes Matematika sedang dan sisanya $11,21 \%$ dari total sampel memiliki nilai tes Matematika tinggi.

2. Siswa laki-laki dalam penelitian yang memiliki nilai tes Matematika rendah sebanyak 33 orang dan siswa perempuannya sebanyak 35 orang. Sedangkan siswa laki-laki yang memiliki persepsi sedang sebanyak 17 orang dan siswa perempuan sebanyak 10 orang. Serta siswa laki-laki yang memiliki persepsi tinggi sebanyak 6 orang dan siswa perempuannya sebanyak 6 orang. Jadi berdasarkan masing-masing tingkatannya, baiksiswa laki-laki dan perempuan lebih dominan pada tingkat persepsi rendah, meskipun tidak terdapat banyak berbedaan jumlah.

3. Siswa yang memiliki persepsi rendah sebanyak 11 orang, dan sedang 75 siswa serta yang memiliki persepsi tinggi sebanyak 21 siswa. Hal ini menunjukkan bahwa sebagian besar $(70,09 \%)$ siswa memiliki persepsi sedang terhadap matematika. Jumlah responden laki-laki adalah 56 siswa dan responden perempuan 51 siswa.

4. Siswa laki-laki dalam penelitian yang memiliki persepsi rendah sebanyak 5 orang dan siswa perempuannya sebanyak 6 orang. Sedangkan siswa laki-laki yang memiliki persepsi sedang sebanyak 41 orang dan siswa perempuan sebanyak 34 orang. Serta siswa laki-laki yang memiliki persepsi tinggi sebanyak 10 orang dan siswa perempuannya sebanyak 11 orang. Jadi berdasarkan masing - masing tingkatannya, siswa laki-laki lebih dominan pada tingkat persepsi sedang. Meskipun tidak terdapat banyak berbedaan jumlah.

5. Nilai sig untuk gender adalah sebesar $0,816>0,05$, maka dapat disimpulkan bahwa tidak terdapat perbedaan nilai metematika yang dipengaruhi oleh gender.

6. Nilai sig untuk persepsi adalah sebesar $0,924>0,05$, maka dapat disimpulkan bahwa tidak terdapat perbedaan nilai metematika yang dipengaruhi oleh tinggi rendahnya persepsi.

\section{SARAN}

Berdasarkan hasil kesimpulan penelitian yang telah diperoleh, maka dapat diberikan saran-saran sebagai berikut:

1. Bagi siswa, untuk meningkatkan persepsi positifnya terhadap matematika dan dapat terus meningkatkan belajarnya.

2. Bagi guru, untuk memberikan motivasi kepada siswa agar siswa memiliki persepsi yang positif terhadap matematika.

3. Bagi penelitian selanjutnya, dapat menjadi inspirasi untuk melakukan penelitian dijenjang selanjutnya, sekaligus pengembangan perangkat yang sesuai dengan keunikan gender.

\section{DAFTAR PUSTAKA}

Arikunto, S. 2006. Prosedur Penelitian. Jakarta: Rineka Cipta.

Casey, dkk. 2001. Spatial Mechanical Reasoning Skills Versus Math SelfConfidence as Mediators of Gender Differences on Math Subtests Using Cross National Gender-Based Items. Journal for Research in Math Education.

Dahar, W. R. 1988. Teori-teori Belajar. Jakarta: Depdikbud.

Darmanto, H. A. 1997. Hubungan Antara Aspirasi dan Persepsi Warga Belajar Terhadap Program Kerja Paket B Setara SLTP, Serta Dukungan Orangtua Warga Beljar 
Dengan Prestasi Belajar Warga

Belajar Kejar Paket B Setara

SLTP di Kabupaten Jember. Tidak

Diterbitkan. Tesis. Malang:

Program Pascasarjana IKIP

Malang.

Gredler, M. E. B. 1986. Belajar dan Membelajarkan. Terjemahan oleh Munandir. 1991. Jakarta: Rajawali Pers.

Hanna, F. J. 2000. The Power of Perception: Toward A Model of Cultural Oppression and Liberation. Journal of Counseling and Development.

Hudojo, H. 1998. Mengajar Belajar Matematika. Depdikbud, Jakarta.

Kartono, K. 1989. Psikologi Wanita: Mengenal Gadis Remaja dan Wanita Dewasa. Bandung: CV Mandar Maju.

Nirwana, H. 2003. Hubungan Tingkat Aspirasi dan Persepsi Tentang Belajar Dengan Hasil Belajar Matematika Siswa SMU yang Berlatar Belakang Budaya Minangkabau dan Batak. Tidak Diterbitkan. Disertasi. Malang: Program Pascasarjana UM Malang.

Nurgiyantoro, Burhan. 2004. Statistik Terapan Untuk Penelitian Ilmuilmu Sosial. Yogyakarta: Gajahmada University Press.

Slameto. 1995. Belajar dan Faktor-faktor yang Mempengaruhinya. Jakarta: Bina Aksara.

Sugiyono. 2002. Metode Penelitian Administrasi. Bandung: Alfabeta. 